\title{
Treating early dementia: Drug targeting and circumventing the blood-brain barrier
}

\author{
Joseph S. D'Arrigo* \\ Cavitation-Control Technology Inc., Farmington, CT 06032, USA
}

\begin{abstract}
Over past decades, a frequent co-morbidity of cerebrovascular pathology and Alzheimer's disease pathology has been observed. Accordingly, much evidence has been reported which indicates that microvascular endothelial dysfunction, due to cerebrovascular risk factors (e.g., atherosclerosis, diabetes, obesity, hypertension, smoking, aging), precedes cognitive decline in Alzheimer's disease and contributes to its pathogenesis. These findings indicate that preservation of healthy cerebrovascular endothelium can be an important therapeutic target. Versatile small-molecule drug(s) targeting multiple pathways of Alzheimer's disease pathogenesis are known. By incorporating such drug(s) into the targeted "lipid-coated microbubble/nanoparticle-derived" (LCM/ND) lipid nanoemulsion type, one obtains a multitasking combination therapeutic for translational medicine. This multitasking therapeutic targets certain cell-surface scavenger receptors, mainly class B type I (i.e., SR-BI), making it possible for various Alzheimer's-related cell types to be simultaneously searched out for localized drug treatment in vivo. Besides targeting cell-surface SR-BI, the proposed LCM/ND-nanoemulsion combination therapeutic(s) include a characteristic lipid-coated microbubble (LCM) subpopulation (i.e., a stable LCM suspension); such LCM would facilitate accomplishing transcranial sonoporation (if additionally, desired for the Alzheimer's patient) and assist in advancing sonoporation to the clinic.
\end{abstract}

\section{Introduction}

The fundamental involvement of the cerebrovasculature in the pathogenesis of common dementias, widely reported in the biomedical literature, has recently been reviewed (e.g. [1,2]). In fact, vascular brain lesions are very common in people over 70 years old, and a large proportion of dementia cases may be attributable to cerebrovascular disease. Small-vessel disease is commonly found in patients who have other brain pathologies, such as the plaques and tangles associated with neurodegenerative disease; small-vessel disease also increases the risk of Alzheimer's disease. Accordingly, vascular cognitive impairment and dementia (VCID) is the second leading cause of dementia behind Alzheimer's disease, and is a frequent co-morbidity in the Alzheimer's patient [3-9]. On a worldwide basis, 36 million people had dementia in 2010; of these dementia patients, $60 \%-80 \%$ have Alzheimer's disease $[4,10,11]$.

\section{Central role of endothelial dysfunction}

It has been reported that nanocomplexes can be readily transported into brain capillary endothelial cells (bovine and porcine) via SRBI receptor-mediated endocytosis [12-15]. Accordingly, endothelial modulation and repair become feasible by pharmacological targeting [16-26] via SR-BI receptors (cf. [25]). As the detailed review by Mahringer et al. [27] points out, the blood-brain barrier (BBB) is equipped with several endocytic receptors at the luminal surface (i.e., the capillary endothelial membrane), including the type BI scavenger receptor (SR-BI). These authors explain that, after i.v. injection, surfactant/lipid-coated nanoparticles apparently bind to apolipoproteins (for example, apoA-I in blood plasma) and are subsequently recognized by the corresponding lipoprotein receptors, namely (in the presence of apoA-I), SR-BI type scavenger receptors at the BBB [1].
Furthermore, very recently published experimental work (in human-endothelial-cell monolayer cultures as well as in threedimensional tissue-engineered human vessels) has demonstrated in detail [28] that HDL, acting via scavenger receptors (class B type I, i.e., SR-BI), blocks $\beta$-amyloid uptake into endothelial cells - in experimental monolayers as well as, the authors argue, in the human cerebrovascular endothelium $[1,2]$. These authors also point out that SR-BI is the principal HDL receptor on (human brain microvascular) endothelial cells and activates several HDL-signaling pathways (in addition to mediating selective cholesterol uptake) upon HDL docking. The authors observed that inhibiting SR-BI binding with a specific blocking antibody abolished the ability of HDL to suppress " $\beta$-amyloidinduced" monocyte adhesion to (human microvascular) endothelial cells [28]. It is worth noting that such blood-borne human monocytes (with their high expression of CLA-1 (the human SR-BI ortholog [29]) and/or SR-BI, as well as their ability to differentiate into macrophages to elicit an immune response locally) have recently been reported [30] (cf. [31]) to reduce Alzheimer's-like pathology and associated cognitive impairments in transgenic mice having Alzheimer's-like symptoms (refer [1] for a review).

Fung et al. [32] separately report that SR-BI mediates the uptake and transcytosis of HDL in brain microvascular endothelial cells (i.e., across the blood-brain barrier). These investigators further argue that manipulation of $\mathrm{HDL}$ transcytosis across the $\mathrm{BBB}$ to increase

Correspondence to: Joseph S. D’Arrigo, Cavitation-Control Technology Inc., Farmington, CT 06032, USA, E-mail: cavcon@ntplx.net

Key words: Alzheimer's disease; drug targeting; nanoemulsion; SR-BI; scavenger receptors; transcranial sonoporation

Received: January 2, 2018; Accepted: February 25, 2018; Published: February 28,2018 
delivery of plasma apolipoprotein A-I (apoA-I) may, in turn, facilitate increasing the transport of "HDL-like synthetic particles" containing therapeutic drug across the BBB to treat neurodegenerative disorders such as Alzheimer's disease [32]. Therefore, the recently reviewed $[1,2]$ "lipid-coated microbubble/nanoparticle-derived" (LCM/ND) nanoemulsion (refer below) can arguably serve as a targeted, apoA-Ibased, (SR-BI mediated) therapeutic agent for Alzheimer's disease and vascular dementia [28,33-35] (cf. [36-42]).

\section{Targeted drug treatment for early dementia}

This targeted-drug-delivery therapeutic approach, using the proposed LCM/ND lipid nanoemulsion for treating the more common (late-onset) dementias, receives added impetus from continual findings of cerebrovascular pathology [43-53] and an apparent endotheliumdysfunction [33-41,49,54-60] in both Alzheimer's disease and its major risk factors [53-72]. By incorporating drug candidates (such as Edaravone, DHA, or antibody therapeutics) into the LCM/ND lipid nanoemulsion type, known to be a successful drug carrier $[73,74]$, one is likely to obtain a multitasking combination therapeutic for translational medicine. This therapeutic agent would target cell-surface SR-BI making it possible for various (above-described) cell types, all potentially implicated in Alzheimer's disease (refer [1,2] for reviews; cf. $[71,72])$, to be simultaneously sought out and better reached for localized drug treatment of brain tissue in vivo. It is also possible that targeting multiple cellular sites, within the multiple-cell-type network underlying Alzheimer's disease pathophysiology, may be successful even when each (SR-BI bearing) cell type targeted is affected in a relatively modest way; that is to say, the effects on the various cell types targeted may be additive, multiplicative, or otherwise synergistic [26].

With regard to receptor-mediated membrane transport across the $\mathrm{BBB}$, brain microvascular endothelial cells are believed to control iron uptake and efflux, under the direct guidance of neighboring astrocytes [75,76]. Detailed evidence has been reported recently [75] showing that human brain microvascular endothelial cells, which constitute most of the blood-brain barrier, receive brain-iron status information via paracrine signals from ensheathing astrocytes. Lastly, aging, obesity, and smoking are significant determinants of brain iron accumulation in human subjects [77] and all have been long-associated with Alzheimer's disease incidence [25,50-52,54,55,65,78-80].

Note that the above-mentioned (cf. preceding paragraph and Abstract) long association of specifically both obesity and diabetes with Alzheimer's disease incidence has also renewed attention to the brain's main facilitative glucose transporter protein, GLUT-1, involvement in and probable contribution to neurodegenerative diseases [81-83]. More than two decades ago it was already recognized that normal humanbrain capillary endothelium has a high density of GLUT-1, whereas the cerebral microvessels in subjects with Alzheimer's disease showed a markedly decreased GLUT-1 density when compared with age-matched controls [84,85]. More recently, Winkler et al. [86] demonstrated that GLUT-1 deficiency in cerebral endothelium (but not in astrocytes), in a mouse model of Alzheimer's disease, initiates blood-brain barrier breakdown. These authors observed from their detailed experiments that reduced GLUT-1 expression (at the BBB) worsens Alzheimer's disease cerebrovascular degeneration, neuropathology, and cognitive function - suggesting that (cerebral endothelial) GLUT-1 may represent a therapeutic target for Alzheimer's disease vasculo-neuronal dysfunction and degeneration [86]. Further, other investigators [87] (cf. [88]) have recently provided evidence for brain glucose dysregulation as a critical event in Alzheimer's disease pathogenesis that closely reflects both the severity of Alzheimer's disease pathology and the expression of symptoms. Moreover, abnormalities in brain glucose homeostasis may begin several years before the onset of clinical symptoms [87].

In summary, endothelial cells are the main component of the $\mathrm{BBB}$, which is seriously disrupted in various neurological pathologies - including many neurodegenerative disorders [89-91]. An early BBB breakdown and/or dysfunction has been documented [92] in Alzheimer's disease before dementia, neurodegeneration, and/or brain atrophy occur, and investigators have reported that targeting the BBB can influence the course of neurological disorder [92]. Hence, vascular-targeted therapies become plausible for the prevention and treatment of common dementias [4,36,89,93-95]. In respect to vascular tone, vasodilators (nitric oxide, acetylcholine) are repressed while vasoconstrictor (endothelin-1) is enhanced, thus contributing to endothelial dysfunction in Alzheimer's disease $[90,96]$. Also, $\beta$-amyloid can induce apoptosis and/or necrosis of brain endothelial cells. Presence of $\beta$-amyloid, as well as tau protein oligomers, leads to accumulation of inflammatory molecules in microvessels - which further fosters endothelial dysfunction [90,97-99]. Other component cell types of the neurovascular unit are affected as well in Alzheimer's disease [90]. For example, deposition and aggregation of $\beta$-amyloid within vascular smooth muscle cells leads to inflammation, oxidative stress, impaired vasorelaxation, and disruption of BBB integrity. At the same time, midlife vascular-risk factors such as hypertension, cardiovascular disease, diabetes, dyslipidemia, and obesity all increase the relative risk for Alzheimer's disease [89,100-103]. These comorbidities are all characterized by low and/or dysfunctional HDL, which itself is an Alzheimer's risk factor. Namely, (in addition to long-published lipid transport,) HDL regulates vascular health via modulating vasorelaxation, inflammation, and oxidative stress as well as promoting endothelial cell survival and integrity $[36,102,104]$. Since SR-BI has already been identified as a major receptor for HDL (with their major apolipoprotein (apo)A-I) as well as for the earlierdescribed LCM/ND nanoemulsion [1,2], this multitasking lipid nanoemulsion can arguably serve as a targeted, apoA-I-based, (SR-BI mediated) therapeutic agent for common (late-onset) dementias (cf. [28,33,35,37-42]).

\section{Promising developments regarding supplementary neurotherapy using targeted sonoporation}

A completely separate and additional advantage of such LCM/ ND (drug-delivery) nanoemulsion(s) stems from the characteristic lipid-coated microbubble (LCM) subpopulation existing in this nanoemulsion type $[1,2]$. This characteristic LCM subpopulation would now be available to substantially reduce the acoustic power levels needed for accomplishing endothelial sonoporation (refer [1] for a review), if additionally desired for further targeted (transcranial) neurotherapy (cf. [105-120]) of the Alzheimer's patient. Over the past decade, neuroscientists have been exploring the use of ultrasound in combination with preformed (intravenous) microbubbles to temporarily open the BBB [1,2,121-126], allowing drugs or the immune system to target brain tumors or Alzheimer's brain plaque in vivo effectively, repeatedly, and safely [127-133] in animals up to primates $[127,134]$ and even in humans [134]. It is believed that (nonthermal focused) ultrasound pulses cause the (intravenously injected) preformed microbubbles to expand and contract (with acoustic pressure rarefaction and compression, respectively) against the BBB structure, thereby loosening the tight junctions [135,136] between endothelial cells which form the structural core of the BBB. Recently, this research approach was employed by Leinenga and Gotz [135] who utilized focused (transcranial) ultrasound coupled with intravenous 
injection of lipid-encased microbubbles. These authors concluded that their findings suggest that microbubble-assisted ultrasound irradiation is useful for removing $\beta$-amyloid plaques in the mouse brain without causing observable damage, and should be explored further as a noninvasive method with potential as a (non-pharmacological) therapeutic approach for Alzheimer's disease $[1,2,135,136]$.

It is worth noting that the above-proposed mechanism of plaqueburden reduction, by sonoporation (i.e., "loosening the tight junctions of the cells forming the BBB" $[135,136])$, might carry an additional effect. (Microbubble-assisted) sonoporation not only facilitates localized delivery of drugs and/or "activated" immune cells to target Alzheimer's brain plaque in vivo [135], but also facilitates (passivetransport?) reduction of $\beta$-amyloid plaque burden from brain tissue in a mouse model of Alzheimer's disease [137]. Specifically, this same mechanism might also function to counteract characteristic decreased "brain clearance" of neurotoxic $\beta$-amyloid "monomer" [137]- which has been described as a central event in the pathogenesis of Alzheimer's disease (cf. $[1,2,138])$. Namely, the recent biomolecular study by Keaney et al. reports that controlled modulation of tight junction components at the BBB can enhance the clearance (into the plasma) of soluble human $\beta$-amyloid monomers from the brain in a murine model of Alzheimer's disease [137].

The actual cellular and biophysical mechanism(s) of the reversible $\mathrm{BBB}$ “opening” process from sonoporation, when employing focused transcranial ultrasound coupled with injected preformed microbubbles, has been described further in other published studies over the last several years [1,139-145]. For example, the preformed microbubbles concentrate the ultrasound effects to the microvasculature, greatly reducing the ultrasound exposure levels needed to produce bioeffects; thus, with injected microbubbles one can apply focused ultrasound transcranially without significant skull heating $[139,140]$. Moreover, other investigators have recently pointed out [144,145] that microbubble-mediated sonoporation is also believed to actually enhance local drug uptake across the cell membrane itself (e.g., of endothelial cells). Hence, CNS-endothelial sonoporation offers a range of neurotherapeutic options that can include either: (1) inducing/ facilitating endocytosis (and, in turn, transcytosis); (2) transient cellular-pore generation; and/or (3) widening of tight junctions between endothelial cells of the cerebral microvasculature. These varied neurotherapeutic options are important and useful, for both the researcher and the clinician, because the BBB disruption associated with various neurological disorders (e.g., Alzheimer's disease, vascular dementia) has not been characterized in full detail cellularly [1]. In the foreseeable future, taking full advantage of this ongoing, noninvasive, and targeted use of preformed (such as LCM/ND nanoemulsion-based) microbubbles with sonoporation, while optimizing drug-delivery efficiency (through judicious choice of acoustic parameters [129,133]) and minimizing side effects, may assist in advancing sonoporation to the clinic (cf. [1,144-150]).

In this neurotherapeutic approach to the clinic, both the researcher and the clinician are still faced with the challenge of translation from rodent to large animal or man - yet significant progress on minimizing potential side effects, in large-animal transcranialultrasound work, has already been reported in the literature (refer [1] for a review). For example, an earlier study by Xie et al. [140] in pigs has demonstrated that intravenous lipid-encapsulated microbubbles, combined with transtemporal-applied $1-\mathrm{MHz}$ ultrasound, can transiently and reversibly increase BBB permeability in a largeanimal model. These authors explain that their study achieved an alteration in BBB permeability with lower peak negative pressures and lower doses of ultrasound contrast (i.e., intravenous, film-stabilized microbubbles) in a large-animal model and, thus, transient alterations in BBB permeability sufficient for enhanced drug delivery and without unwanted bioeffects (hemorrhage, necrosis, apoptosis) [140] in human subjects appear increasingly feasible (refer [1,2] for added discussion).

\section{Conclusion}

The proposed multitasking combination therapeutic may also display greater efficacy at different stages of Alzheimer's disease (cf. [72]); as a result, this multitasking (drug-delivery) therapeutic could represent a promising way to treat, delay, or even prevent the disease in the future $[1,2]$. In addition, preformed (lipid-stabilized) microbubbles, as contained within this combination therapeutic $[1,73]$, are known to substantially reduce the acoustic power levels needed for accomplishing temporary noninvasive (transcranial) ultrasound treatment [1,105109,111-113,130,151-156], or sonoporation [1,110,114-119,157-159], if additionally desired for the Alzheimer's patient.

\section{Funding Sources}

This research did not receive any specific grant from funding agencies in the public, commercial, or not-for-profit sectors. J.S.D. is an employee of Cav-Con Inc.

\section{Conflicts of Interest}

Beyond the above employment, the author declares no potential conflicts of interest.

\section{Acknowledgments}

Many thanks are due to numerous past (basic-research and clinical) colleagues for cultivating important collaboration, over the past few decades, on some of the published investigations described in this review and/or their generous help with various experimental measurements.

\section{References}

1. D'Arrigo JS (2017) Alzheimer's disease, brain injury, and C.N.S. nanotherapy in humans: Sonoporation augmenting drug targeting. Medical Sciences 5: 29. [Crossref]

2. D'Arrigo JS (2018) Nanotherapy for Alzheimer's disease and vascular dementia: Targeting senile endothelium. Adv Colloid Interface Sci 251: 44-54. [Crossref]

3. Cooper LL, Mitchell GF (2016) Aortic Stiffness, Cerebrovascular Dysfunction, and Memory. Pulse (Basel) 4: 69-77. [Crossref]

4. Dichgans M, Leys D (2017) Vascular Cognitive Impairment. Circ Res 120: 573-591 [Crossref]

5. The Lancet Neurology (2017) Vascular disease and neurodegeneration: advancing together. Lancet Neurol 16: 333. [Crossref]

6. Kalaria RN (2016) Neuropathological diagnosis of vascular cognitive impairment and vascular dementia with implications for Alzheimer's disease. Acta Neuropathol 131: 659-685. [Crossref]

7. Duncombe J, Kitamura A, Hase Y, Ihara M, et al. (2017) Chronic cerebral hypoperfusion: a key mechanism leading to vascular cognitive impairment and dementia. Closing the translational gap between rodent models and human vascular cognitive impairment and dementia. Clin Sci (Lond) 131: 2451-2468. [Crossref]

8. Perrotta M, Lembo G, Carnevale D (2016) Hypertension and Dementia: Epidemiologica and Experimental Evidence Revealing a Detrimental Relationship. Int J Mol Sci 17: 347. [Crossref]

9. Sudduth TL, Weekman EM, Price BR, Gooch JL, Woolums A, et al. (2017) Timecourse of glial changes in the hyperhomocysteinemia model of vascular cognitive impairment and dementia (VCID). Neuroscience 341: 42-51. [Crossref]

10. Bhat NR (2015) Vasculoprotection as a Convergent, Multi-Targeted Mechanism of Anti-AD Therapeutics and Interventions. J Alzheimers Dis 46: 581-591. [Crossref] 
11. Manukhina EB, Downey HF, Shi X, Mallet RT (2016) Intermittent hypoxia training protects cerebrovascular function in Alzheimer's disease. Exp Biol Med 241: 13511363. [Crossref]

12. Srimanee A, Regberg J, Hallbrink M, Vajragupta O, Langel U (2016) Role of scavenger receptors in peptide-based delivery of plasmid DNA across a blood-brain barrier model. Int J Pharm 500: 128-135. [Crossref]

13. Lajoie JM, Shusta EV (2015) Targeting receptor-mediated transport for delivery of biologics across the blood-brain barrier. Annu Rev Pharmacol Toxicol 55: 613-631. [Crossref]

14. Almer G, Mangge H, Zimmer A, Prassl R (2015) Lipoprotein-Related and Apolipoprotein-Mediated Delivery Systems for Drug Targeting and Imaging. Curr Med Chem 22: 3631-3651. [Crossref]

15. Preston JE, Joan Abbott N, Begley DJ (2014) Transcytosis of macromolecules at the blood-brain barrier. Adv Pharmacol 71: 147-163. [Crossref]

16. Di Marco LY, Venneri A, Farkas E, Evans PC, Marzo A, et al. (2015) Vascular dysfunction in the pathogenesis of Alzheimer's disease--A review of endotheliummediated mechanisms and ensuing vicious circles. Neurobiol Dis 82: 593-606. [Crossref]

17. Salmina AB, Inzhutova AI, Malinovskaya NA, Petrova MM (2010) Endothelia dysfunction and repair in Alzheimer-type neurodegeneration: neuronal and glial control. J Alzheimers Dis 22: 17-36. [Crossref]

18. Tong XK, Hamel E (2015) Simvastatin restored vascular reactivity, endothelial function and reduced string vessel pathology in a mouse model of cerebrovascular disease. J Cereb Blood Flow Metab 35: 512-520. [Crossref]

19. Carradori D, Gaudin A, Brambilla D, Andrieux K (2016) Application of Nanomedicine to the CNS Diseases. Int Rev Neurobiol 130: 73-113. [Crossref]

20. Koster KP, Thomas R, Morris AW, Tai LM (2016) Epidermal growth factor prevents oligomeric amyloid- $\beta$ induced angiogenesis deficits in vitro. $J$ Cereb Blood Flow Metab 36: 1865-1871.

21. Zenaro E, Piacentino G, Constantin G (2017) The blood-brain barrier in Alzheimer's disease. Neurobiol Dis 107: 41-56. [Crossref]

22. Qosa H, Mohamed A, Al Rihani SB, Batarseha YS, Duong QV, Keller JN, Kaddoumi A (2016) High-throughput screening for identification of blood-brain barrier integrity enhancers: A drug repurposing opportunity to rectify vascular amyloid toxicity. $J$ Alzheimers Dis 53: 1499-1516.

23. Hostenbach S, D'haeseleer M, Kooijman R, De Keyser J (2016) The pathophysiological role of astrocytic endothelin-1. Prog Neurobiol 144: 88-102. [Crossref]

24. Koizumi K, Wang G, Park L (2016) Endothelial Dysfunction and Amyloid- $\hat{I}^{2}$-Induced Neurovascular Alterations. Cell Mol Neurobiol 36: 155-165. [Crossref]

25. Goldwaser EL, Acharya NK, Sarkar A, Godsey G, Nagele RG (2016) Breakdown of the cerebrovasculature and blood-brain barrier: A mechanistic link between diabetes mellitus and Alzheimer's disease. J Alzheimers Dis 54: 445-456. [Crossref]

26. Bredesen DE (2014) Reversal of cognitive decline: a novel therapeutic program. Aging (Albany NY) 6: 707-717. [Crossref]

27. Mahringer A, Reichel V, Ott M, MacLean C, Reimold I, Hollnack-Pusch E, Fricker G (2012) Overcoming the blood brain barrier: The challenge of brain drug targeting. $J$ Nanoneurosci 2: 5-19.

28. Robert J, Button EB, Stukas S, Boyce GK, Gibbs E, Cowan CM, Gilmour M, Cheng WH, Soo SK, Yuen B, et al. (2017) High-density lipoproteins suppress Aßinduced PBMC adhesion to human endothelial cells in bioengineered vessels and in monoculture. Mol Neurodegener 12: 60, doi:10.1186/s13024-017-0201-0. [Crossref]

29. Vishnyakova TG, Bocharov AV, Baranova IN, Chen Z, Remaley AT, et al. (2003) Binding and internalization of lipopolysaccharide by CLA-1, a human orthologue of rodent scavenger receptor B1. J Biol Chem 278: 22771-22780.

30. Darlington D, Li S, Hou H, Habib A, Tian J, et al. (2015) Human umbilical cord bloodderived monocytes improve cognitive deficits and reduce amyloid- $\beta$ pathology in PSAPP mice. Cell Transplant 24: 2237-2250. [Crossref]

31. Chang EH, Rigotti A, Huerta PT (2009) Age-related influence of the HDL receptor SR-BI on synaptic plasticity and cognition. Neurobiol Aging 30: 407-419. [Crossref]

32. Fung KYY, Wang C, Nyegaard S, Heit B, Fairn G, Lee W (2017) Scavenger receptor $\mathrm{BI}$ mediates the uptake and transcytosis of HDL in brain microvascular endothelial cells independent of PDZK1 and nitric oxide. FASEB J 31: S783.1. [Crossref]
33. Robert J, Stukas S, Button E, Cheng WH, Lee M, et al. (2016) Reconstituted highdensity lipoproteins acutely reduce soluble brain A $\beta$ levels in symptomatic APP/PS1 mice. Biochim Biophys Acta 1862: 1027-1036.

34. Armstrong SM, Sugiyama MG, Fung KY, Gao Y, Wang C, et al. (2015) A novel assay uncovers an unexpected role for SR-BI in LDL transcytosis. Cardiovasc Res 108: 268277. [Crossref]

35. Hottman DA, Chernick D, Cheng S, Wang Z, Li L (2014) HDL and cognition in neurodegenerative disorders. Neurobiol Dis $72 \mathrm{Pt}$ A: 22-36. [Crossref]

36. Velagapudi S, Yalcinkaya M, Piemontese A, Meier R, Norrelykke SF, et al. (2017) VEGF-A regulates cellular localization of SR-BI as well as transendothelial transport of HDL but not LDL. Arterioscler Thromb Vasc Biol 37: 794-803.

37. Choi HJ, Seo EH, Yi D, Sohn BK, Choe YM, et al. (2016) Amyloid-independent amnestic mild cognitive impairment and serum apolipoprotein A1 levels. Am J Geriatr Psychiatry 24: 144-153. [Crossref]

38. Kitamura Y, Usami R, Ichihara S, Kida H, Satoh M, et al. (2017) Plasma protein profiling for potential biomarkers in the early diagnosis of Alzheimer's disease. Neurol Res 39: 231-238. [Crossref]

39. Lazarus J, Mather KA, Armstrong NJ, Song F, Poljak A, et al. (2015) DNA methylation in the apolipoprotein-A1 gene is associated with episodic memory performance in healthy older individuals. J Alzheimers Dis 44: 175-182. [Crossref]

40. Ma C, Li J, Bao Z, Ruan Q, Yu Z (2015) Serum Levels of ApoA1 and ApoA2 Are Associated with Cognitive Status in Older Men. Biomed Res Int 2015: 481621 [Crossref]

41. Slot RE, Van Harten AC, Kester MI, Jongbloed W, Bouwman FH, et al. (2017) Apolipoprotein A1 in Cerebrospinal Fluid and Plasma and Progression to Alzheimer's Disease in Non-Demented Elderly. J Alzheimers Dis 56: 687-697. [Crossref]

42. Yin ZG, Li L, Cui M, Zhou SM, Yu MM, et al. (2014) Inverse relationship between apolipoprotein A-I and cerebral white matter lesions: A cross-sectional study in middleaged and elderly subjects. PLOS ONE 9: e97113. [Crossref]

43. Weekman EM, Sudduth TL, Caverly CN, Kopper TJ, Phillips OW, et al. (2016) Reduced efficacy of anti-A $\mathrm{B}$ immunotherapy in a mouse model of amyloid deposition and vascular cognitive impairment comorbidity. J Neurosci 36: 9896-9907.

44. Nelson AR, Sweeney MD, Sagare AP, Zlokovic BV (2016) Neurovascular dysfunction and neurodegeneration in dementia and Alzheimer's disease. Biochim Biophys Acta 1862: 887-900. [Crossref]

45. Kapasi A, Schneider JA (2016) Vascular contributions to cognitive impairment, clinical Alzheimer's disease, and dementia in older persons. Biochim Biophys Acta 1862: 878-886

46. McAleese KL, Alafuzoff I, Charidimou A, De Reuck J, Grinberg LT, et al. (2016) Post-mortem assessment in vascular dementia: Advances and aspirations. BMC Med 14: 129.

47. Noh Y, Seo SW (2016) The Role of Cerebrovascular Disease in Amyloid Deposition. $J$ Alzheimers Dis 54: 1015-1026. [Crossref]

48. Hishikawa N, Fukui Y, Sato K, Kono S, Yamashita T, et al. (2016) Cognitive and affective functions in Alzheimer's disease patients with metabolic syndrome. Eur $J$ Neurol 23: 339-345. [Crossref]

49. Gutierrez J, Honig L, Elkind MS, Mohr JP, Goldman J, et al. (2016) Brain arterial aging and its relationship to Alzheimer dementia. Neurology 86: 1507-1515. [Crossref]

50. Nagata K, Yamazaki T, Takano D, Maeda T, Fujimaki Y, et al. (2016) Cerebral circulation in aging. Ageing Res Rev 30: 49-60. [Crossref]

51. Calabrese V, Giordano J, Signorile A, Ontario ML, Castorina S, et al. (2016) Major pathogenic mechanisms in vascular dementia: Roles of cellular stress response and hormesis in neuroprotection. J Neurosci Res 94: 1588-1603.

52. Toth P, Tarantini S, Csiszar A, Ungvari ZI (2017) Functional vascular contributions to cognitive impairment and dementia: Mechanisms and consequences of cerebral autoregulatory dysfunction, endothelial impairment, and neurovascular uncoupling in aging. Am J Physiol Heart Circ Physiol 312: H1-H20.

53. Devraj K, Poznanovic S, Spahn C, Schwall G, Harter PN, et al. (2016) BACE-1 is expressed in the blood-brain barrier endothelium and is upregulated in a murine model of Alzheimer's disease. J Cereb Blood Flow Metab 36: 1281-1294.

54. Chao AC, Lee TC, Juo SH, Yang DI (2016) Hyperglycemia increases the production of amyloid beta-peptide leading to decreased endothelial tight junction. CNS Neurosci Ther 22: 291-297. 
55. Khalil RB, Khoury E, Koussa S (2016) Linking multiple pathogenic pathways in Alzheimer's disease. World J Psychiatry 6: 208-214.

56. Festoff BW, Sajja RK, van Dreden P, Cucullo L (2016) HGMB1 and thrombin mediate the blood-brain barrier dysfunction acting as biomarkers of neuroinflammation and progression to neurodegeneration in Alzheimer's disease. $J$ Neuroinflamm 13: 194. [Crossref]

57. Gangoda SV, Butlin M, Gupta V, Chung R, Avolio A (2016) Pulsatile stretch alters expression and processing of amyloid precursor protein in human cerebral endothelial cells. J Hypertens 34: e24. [Crossref]

58. Roberts AM, Jagadapillai R, Vaishnav RA, Friedland RP, Drinovac R, et al. (2016) Increased pulmonary arteriolar tone associated with lung oxidative stress and nitric oxide in a mouse model of Alzheimer's disease. Physiol Rep 4: e12953. [Crossref]

59. Shang S, Yang YM, Zhang H, Tian L, Jiang JS, et al. (2016) Intracerebral GM-CSF contributes to transendothelial monocyte migration in APP/PS1 Alzheimer's disease mice. J Cereb Blood Flow Metab 36: 1987-1991.

60. Austin SA, Katusic ZS (2016) Loss of Endothelial Nitric Oxide Synthase Promotes p25 Generation and Tau Phosphorylation in a Murine Model of Alzheimer's Disease. Circ Res 119: 1128-1134. [Crossref]

61. Katusic ZS, Austin SA (2016) Neurovascular Protective Function of Endothelial Nitric Oxide - Recent Advances. Circ J 80: 1499-1503. [Crossref]

62. Wang L, Du Y, Wang K, Xu G, Luo S, et al. (2016) Chronic cerebral hypoperfusion induces memory deficits and facilitates $\mathrm{A}^{2}$ generation in $\mathrm{C} 57 \mathrm{BL} / 6 \mathrm{~J}$ mice. Exp Neurol 283: 353-364. [Crossref]

63. Kyrtsos CR, Baras JS (2015) Modeling the role of the glymphatic pathway and cerebral blood vessel properties in Alzheimer's disease pathogenesis. PLOS ONE 0139574. [Crossref]

64. Kalaria RN, Akinyemi R, Ihara M (2016) Stroke injury, cognitive impairment and vascular dementia. Biochim Biophys Acta 1862: 915-925. [Crossref]

65. Khan A, Kalaria RN, Corbett A, Ballard C (2016) Update on Vascular Dementia. $J$ Geriatr Psychiatry Neurol 29: 281-301. [Crossref]

66. Austin SA, Santhanam AV, d'Uscio LV, Katusic ZS (2015) Regional heterogeneity of cerebral microvessels and brain susceptibility to oxidative stress. PLOS ONE 10: $\mathrm{e} 0144062$.

67. Toda N, Okamura T (2016) Cigarette smoking impairs nitric oxide-mediated cerebral blood flow increase: Implications for Alzheimer's disease. J Pharmacol Sci 131: 223-232.

68. Uiterwijk R, Huijts M, Staals J, Rouhl RP, De Leeuw PW, et al. (2016) Endothelia activation is associated with cognitive performance in patients with hypertension. $\mathrm{Am}$ J Hypertens 29: 464-469.

69. Kamat PK, Kyles P, Kalani A, Tyagi N (2016) Hydrogen Sulfide Ameliorates Homocysteine-Induced Alzheimer's Disease-Like Pathology, Blood-Brain Barrier Disruption, and Synaptic Disorder. Mol Neurobiol 53: 2451-2467. [Crossref]

70. Iadecola C (2016) Untangling Neurons with Endothelial Nitric Oxide. Circ Res 119: 1052-1054. [Crossref]

71. Wang YJ (2014) Alzheimer disease: Lessons from immunotherapy for Alzheimer disease. Nat Rev Neurol 10: 188-189. [Crossref]

72. Krstic D, Knuesel I (2013) Deciphering the mechanism underlying late-onset Alzheimer disease. Nat Rev Neurol 9: 25-34. [Crossref]

73. D'Arrigo J (2011) Stable Nanoemulsions: Self-Assembly in Nature and Nanomedicine. Amsterdam: Elsevier, 415p; ISBN 978-0-444-53798-0.

74. Barbarese E, Ho SY, D'Arrigo JS, Simon RH (1995) Internalization of microbubbles by tumor cells in vivo and in vitro. J Neurooncol 26: 25-34. [Crossref]

75. Beydoun R, Hamood MA, Gomez Zubieta DM, Kondapalli KC (2017) Na+/H+ Exchanger 9 Regulates Iron Mobilization at the Blood-Brain Barrier in Response to Iron Starvation. J Biol Chem 292: 4293-4301. [Crossref]

76. McCarthy RC, Kosman DJ (2015) Iron transport across the blood-brain barrier: Development, neurovascular regulation and cerebral amyloid angiopathy. Cell $\mathrm{Mo}$ Life Sci 72: 709-727.

77. Pirpamer L, Hofer E, Gesierich B, De Guio F, Freudenberger P, et al. (2016) Determinants of iron accumulation in the normal aging brain. Neurobiol Aging 43 : 149-155. [Crossref]

78. Dalkara T, Alarcon-Martinez L (2015) Cerebral microvascular pericytes and neurogliovascular signaling in health and disease. Brain Res 1623: 3-17. [Crossref]
79. Daulatzai MA (2017) Cerebral hypoperfusion and glucose hypometabolism: Key pathophysiological modulators promote neurodegeneration, cognitive impairment, and Alzheimer's disease. J Neurosci Res 95: 943-972. [Crossref]

80. Tarantini S, Tran CHT, Gordon GR, Ungvari Z, Csiszar A (2017) Impaired neurovascular coupling in aging and Alzheimer's disease: Contribution of astrocyte dysfunction and endothelial impairment to cognitive decline. Exp Gerontol 94: 52-58. [Crossref]

81. Barros LF, San Martín A, Ruminot I, Sandoval PY, Fernández-Moncada I, et al (2017) Near-critical GLUT1 and Neurodegeneration. J Neurosci Res 95: 2267-2274. [Crossref]

82. Jais A, Solas M, Backes H, Chaurasia B, Kleinridders A, et al. (2016) Myeloid-cell derived VEGF maintains brain glucose uptake and limits cognitive impairment in obesity. Cell 165:882-895.

83. Keaney J, Campbell M (2015) The dynamic blood-brain barrier. FEBS J 282: $4067-$ 4079. [Crossref]

84. Harik SI (1992) Changes in the glucose transporter of brain capillaries. Can J Physiol Pharmacol 70: S113-S117 [Suppl.].

85. Horwood N, Davies DC (1994) Immunolabelling of hippocampal microvessel glucose transporter protein is reduced in Alzheimer's disease. Virchows Arch 425: 69-72. [Crossref]

86. Winkler EA, Nishida Y, Sagare AP, Rege SV, Bell RD, Perlmutter D, et al. (2015) GLUT1 reductions exacerbate Alzheimer's disease vasculo-neuronal dysfunction and degeneration. Nat Neurosci 18: 521-533.

87. An Y, Varma VR, Varma S, Casanova R, Dammer E, et al. (2017) Evidence for brain glucose dysregulation in Alzheimer's disease. Alzheimers Dement. [Crossref]

88. [Crossref] Yamazaki Y, Kanekiyo T (2017) Blood-Brain Barrier Dysfunction and the Pathogenesis of Alzheimer's Disease. Int J Mol Sci 18.

89. Kelleher RJ, Soiza RL (2013) Evidence of endothelial dysfunction in the development of Alzheimer's disease: Is Alzheimer's a vascular disorder? Am J Cardiovasc Dis 3 : 197-226. [Crossref]

90. Tenreiro MM, Ferreira R, Bernardino L, Brito MA (2016) Cellular response of the blood-brain barrier to injury: Potential biomarkers and therapeutic targets for brain regeneration. Neurobiol Dis 91: 262-273.

91. Yoon CY, Steffen LM, Gross MD, Launer LJ, Odegaard A, Reiner A, et al. (2017) Circulating cellular adhesion molecules and cognitive function: The coronary artery risk development in young adults study. Front Cardiovasc Med 17: 37.

92. Montagne A, Zhao Z, Zlokovic BV, et al. (2017) Alzheimer's disease: A matter of blood-brain barrier dysfunction? J Exp Med 214: 3151-3169. [Crossref]

93. Beishon L, Haunton VJ, Panerai RB (2017) Cerebral Hemodynamics in Mild Cognitive Impairment: A Systematic Review. J Alzheimers Dis 59: 369-385. [Crossref]

94. Love S, Miners JS (2017) Small vessel disease, neurovascular regulation and cognitive impairment: post-mortem studies reveal a complex relationship, still poorly understood. Clin Sci (Lond) 131: 1579-1589. [Crossref]

95. Wang P, Wu Q, Wu W, Li H, Guo Y, Yu P, et al. (2017) Mitochondrial ferritin deletion exacerbates ß-amyloid-induced neurotoxicity in mice. Oxid Med Cell Longev. 1020350.

96. Lourenço CF, Ledo A, Barbosa RM, Laranjinha J (2017) Neurovascular uncoupling in the triple transgenic model of Alzheimer's disease: Impaired cerebral blood flow response to neuronal-derived nitric oxide signaling. Exp Neurol 291: 36-43. [Crossref]

97. Castillo-Carranza DL, Nilson AN, Van Skike CE, et al. (2017) Cerebral Microvascular Accumulation of Tau Oligomers in Alzheimer's Disease and Related Tauopathies. Aging Dis 8: 257-266. [Crossref]

98. Dudvarski Stankovic N, Teodorczyk M, Ploen R, Zipp F, Schmidt MH (2016) Microglia-blood vessel interactions: A double-edged sword in brain pathologies. Acta Neuropathol 131: 347-363.

99. Michalicova A, Banks WA, Legath J, Kovac SA (2017) Tauopathies - focus on changes at the neurovascular unit. Curr Alzheimer Res.

100. Sorop O, Olver TD, van deWouw J, Heinonen I, van Duin RW, et al. (2017) The microcirculation: A key player in obesity-associated cardiovascular disease. Cardiovasc Res: 93.

101. Lee LL, Aung HH, Wilson DW, Anderson SE, Rutledge JC, et al. (2017) Triglyceriderich lipoprotein lipolysis products increase blood-brain barrier transfer coefficient and induce astrocyte lipid droplets and cell stress. Am J Cell Physiol 312: C500-C516. 
102. Stukas S, Robert J, Wellington CL (2014) High-density lipoproteins and cerebrovascular integrity in Alzheimer's disease. Cell Metab 19: 574-591. [Crossref]

103. Swaminathan SK, Ahlschwede KM, Sarma V, Curran GL, Omtri RS, et al. (2017) Insulin differentially affects the distribution kinetics of amyloid beta 40 and 42 in plasma and brain. J Cereb Blood Flow Metab

104. Guilaine B, Emily B, Sonja S, Cheryl W (2017) The pleiotropic vasoprotective functions of high density lipoproteins (HDL). J Biomed Res.

105. Bing C, Ladouceur-Wodzak M, Wanner CR, Shelton JM, Richardson JA, Chopra $\mathrm{R}$ (2014) Trans-cranial opening of the blood-brain barrier in targeted regions using a stereotaxic brain axis and focused ultrasound energy. $J$ Ther Ultrasound 2: 1-11.

106. Lammers T, Koczera P, Fokong S, Gremse F, Ehling J, et al. (2015) Theranostic USPIO-Loaded Microbubbles for Mediating and Monitoring Blood-Brain Barrier Permeation. Adv Funct Mater 25: 36-43. [Crossref]

107. Marquet F, Tung YS, Teichert T, Ferrera VP, Konofagou EE (2011) Noninvasive, transient and selective blood-brain barrier opening in non-human primates in vivo. PLOS ONE 6: e22598.

108. Goliaei A, Adhikari U, Berkowitz ML (2015) Opening of the blood-brain barrier tight junction due to shock wave induced bubble collapse: A molecular dynamics simulation study. ACS Chem Neurosci 6: 1296-1301.

109. Adhikari U, Goliaei A, Berkowitz ML (2015) Mechanism of membrane poration by shock wave induced nanobubble collapse: A molecular dynamics study. JPhys Chem B 119: 6225-6234.

110. Delalande A, Leduc C, Midoux P, Postema M, Pichon C (2015) Efficient gene delivery by sonoporation is associated with microbubble entry into cells and the clathrin-dependent endocytosis pathway. Ultrasound Med Biol 41: 1913-1926.

111. Kotopoulis S, Dimcevski G, Gilja OH, Hoem D, Postema M (2013) Treatment of human pancreatic cancer using combined ultrasound, microbubbles, and gemcitabine: A clinical case study. Med Phys 40: 072902.

112. Kotopoulis S, Delalande A, Popa M, Mamaeva V, Dimcevski G, et al. (2014) Sonoporation-enhanced chemotherapy significantly reduces primary tumour burden in an orthotopic pancreatic cancer xenograft. Mol Imaging Biol 16: 53-62.

113. D'Arrigo JS (2015) Nanotherapy for Alzheimer's. Chem Eng News 93: 2.

114. Paefgen V, Doleschel D, Kiessling F (2015) Evolution of contrast agents for ultrasound imaging and ultrasound-mediated drug delivery. Front Pharmacol 6: 197. [Crossref]

115. Qin J, Wang TY, Willmann JK (2016) Sonoporation: Applications for Cancer Therapy. Adv Exp Med Biol 880: 263-291. [Crossref]

116. Aubry JF, Tanter M (2016) MR-Guided Transcranial Focused Ultrasound. Adv Exp Med Biol 880: 97-111. [Crossref]

117. Castle J, Feinstein SB (2016) Drug and Gene Delivery using Sonoporation for Cardiovascular Disease. Adv Exp Med Biol 880: 331-338. [Crossref]

118. Burgess A, Hynynen K (2016) Microbubble-Assisted Ultrasound for Drug Delivery in the Brain and Central Nervous System. Adv Exp Med Biol 880: 293-308. [Crossref]

119. Bouakaz A, Zeghimi A, Doinikov AA (2016) Sonoporation: Concept and Mechanisms. Adv Exp Med Biol 880: 175-189. [Crossref]

120. Skachkov I, Luan Y, van der Steen AFW, de Jong N, Kooiman K (2014) Targeted microbubble mediated sonoporation of endothelial cells in vivo. IEEE Trans Ultrason Ferrelectr Freq Control 61: 1661-1667.

121. Caskey CF, Stieger SM, Qin S, Dayton PA, Ferrara KW (2007) Direct observations of ultrasound microbubble contrast agent interaction with the microvessel wall. $J$ Acoust Soc Am 122: 1191-1200.

122. Choi JJ, Wang S, Brown TR, Small SA, Duff KE, et al. (2008) Noninvasive and transient blood-brain barrier opening in the hippocampus of Alzheimer's double transgenic mice using focused ultrasound. Ultrason Imaging 30: 189-200. [Crossref]

123. Choi JJ, Selert K, Vlachos F, Wong A, Konofagou EE (2011) Noninvasive and localized neuronal delivery using short ultrasonic pulses and microbubbles. Proc Natl Acad Sci USA 108: 16539-16544.

124. Konofagou EE (2012) Optimization of the ultrasound-induced blood-brain barrier opening. Theranostics 2: 1223-1237. [Crossref]

125. McDannold N, Arvanitis CD, Vykhodtseva N, Livingstone MS (2012) Temporary disruption of the blood-brain barrier by use of ultrasound and microbubbles: Safety and efficacy evaluation in rhesus macaques. Cancer Res 72: 3652-3663.
126. Raymond SB, Skoch J, Hynynen K, Bacskai BJ (2007) Multiphoton imaging of ultrasound/Optison mediated cerebrovascular effects in vivo. J Cereb Blood Flow Metab 27: 393-403. [Crossref]

127. Wu SY, Sanchez CS, Samiotaki G, Buch A (2016) Characterizing FocusedUltrasound Mediated Drug Delivery to the Heterogeneous Primate Brain In Vivo with Acoustic Monitoring. Sci Rep 6: 37094. [Crossref]

128. Song KH, Fan AC, Hinkle JJ, Newman J, Borden MA, et al. (2017) Microbubble gas volume: A unifying dose parameter in blood-brain barrier opening by focused ultrasound. Theranostics 7: 144-152. [Crossref]

129. Chu PC, Chai WY, Tsai CH, Kang ST, et al. (2016) Focused Ultrasound-Induced Blood-Brain Barrier Opening: Association with Mechanical Index and Cavitation Index Analyzed by Dynamic Contrast-Enhanced Magnetic-Resonance Imaging. Sci Rep 6: 33264. [Crossref]

130. Miller DB, O'Callaghan JP (2017) New horizons for focused ultrasound (FUS) therapeutic applications in neurodegenerative diseases. Metabolism 69: S3-S7.

131. Sierra C, Acosta C, Chen C, Wu SY, Karakatsani ME, et al. (2017) Lipid microbubbles as a vehicle for targeted drug delivery using focused ultrasound-induced blood-brain barrier opening. J Cereb Blood Flow Metab 37: 1236-1250. [Crossref]

132. Sun T, Samiotaki G, Wang S, Acosta C, Chen CC, et al. (2015) Acoustic cavitationbased monitoring of the reversibility and permeability of ultrasound-induced bloodbrain barrier opening. Phys Med Biol 60: 9079-9094.

133. Poon C, McMahon D, Hynynen K (2017) Noninvasive and targeted delivery of therapeutics to the brain using focused ultrasound. Neuropharmacology 120: 20-37. [Crossref]

134. Carpentier A, Canney M, Vignot A, Reina V, Beccaria K, et al. (2016) Clinical trial of blood-brain barrier disruption by pulsed ultrasound. Sci Transl Med 8: 343re2. [Crossref]

135. Leinenga G, Gotz J (2015) Scanning ultrasound removes amyloid- $\beta$ and restores memory in an Alzheimer's disease mouse model. Sci Transl Med 7: 278ra33.

136. Torrice M (2015) Alzheimer's therapy goes acoustic. Chem Eng News 93: 5.

137. Keaney J, Walsh DM, O’Malley T, Hudson N, Crosbie DE, et al. (2015) Autoregulated paracellular clearance of amyloid- $\beta$ across the blood-brain barrier. $\mathrm{Scl}$ Adv 1: e1500472.

138. Alexopoulos P, Gleixner LS, Werle L, Buhl F, Thierjung N, Giourou E, Kagerbauer SM, Gourzis P, Kubler H, Grimmer T, et al. (2017) Plasma levels of soluble amyloid precursor protein $B$ in symptomatic Alzheimer's disease. Eur Arch Psychiatry Clin Neurosci 9.

139. Aryal M, Arvanitis CD, Alexander PM, McDannold N (2014) Ultrasound-mediated blood-brain barrier disruption for targeted drug delivery in the central nervous system. Adv Drug Deliv Rev 72: 94-109. [Crossref]

140. Xie F, Boska MD, Lof J, Uberti MG, Tsutsui JM, Porter TR (2008) Effects of transcranial ultrasound and intravenous microbubbles on blood brain barrier permeability in a large animal model. Ultrasound Med Biol 34: 2028-2034.

141. Dasgupta A, Liu M, Ojha T, Storm G, Kiessling F, et al. (2016) Ultrasound-mediated drug delivery to the brain: principles, progress and prospects. Drug Discov Today Technol 20: 41-48. [Crossref]

142. Helfield B, Chen X, Watkins SC, Villanueva FS (2016) Biophysical insight into mechanisms of sonoporation. Proc Natl Acad Sci U S A 113: 9983-9988. [Crossref]

143. van Rooij T, Skachkov I, Beekers I, Lattwein KR, Voorneveld JD, et al. (2016) Viability of endothelial cells after ultrasound-mediated sonoporation: Influence of targeting, oscillation, and displacement of microbubbles. J Control Release 238: 197 211. [Crossref]

144. De Cock I, Zagato E, Braeckmans K, Luan Y, de Jong N, et al. (2015) Ultrasound and microbubble mediated drug delivery: acoustic pressure as determinant for uptake via membrane pores or endocytosis. J Control Release 197: 20-28. [Crossref]

145. Shapiro G, Wong AW, Bez M, Yang F, Tam S, et al. (2016) Multiparameter evaluation of in vivo gene delivery using ultrasound-guided, microbubble-enhanced sonoporation. J Control Release 223: 157-164. [Crossref]

146. Andreone BJ, Chow BW, Tata A, Lacoste B, Ben-Zvi A, et al. (2017) Bloodbrain barrier permeability is regulated by lipid transport-dependent suppression of caveolae-mediated transcytosis. Neuron: 043.

147. Ben-Zvi A, Lacoste B, Kur E, Andreone BJ, Mayshar Y, et al. (2014) Mfsd2a is critical for the formation and function of the blood-brain barrier. Nature 509: 507511. [Crossref] 
148. Chow BW, Gu C (2017) Gradual suppression of transcytosis governs functional blood-retinal barrier formation. Neuron 93: 1325-1333.

149. Aw MS, Paniwnyk L, Losic D (2016) The progressive role of acoustic cavitation for non-invasive therapies, contrast imaging and blood-tumor permeability enhancement. Expert Opin Drug Deliv 13: 1383-1396.

150. Park J, Fan Z, Kumon RE, El-Sayed ME, Deng CX (2010) Modulation of intracellular $\mathrm{Ca} 2+$ concentration in brain microvascular endothelial cells in vitro by acoustic cavitation. Ultrasound Med Biol 36: 1176-1187.

151. Alonso A, Reinz E, Jenne JW, Fatar M, Schmidt-Glenewinkel H, et al. (2010) Reorganization of gap junctions after focused ultrasound blood-brain barrier opening in the rat brain. J Cereb Blood Flow Metab 30: 1394-1402.

152. Alonso A, Reinz E, Fatar M, Hennerici MG, Meairs S (2011) Clearance of albumin following ultrasound-induced blood-brain barrier opening is mediated by glial but not neuronal cells. Brain Res 1411: 9-16.

153. Aslund AKO, Snipstad S, Healey A, Kvale S, Torp SH, et al. (2017) Efficient enhancement of blood-brain barrier permeability using acoustic cluster therapy (ACT). Theranostics 7: 23-30.
154. Delalande A, Kotopoulis S, Postema M, Midoux P, Pichon C (2013) Sonoporation: mechanistic insights and ongoing challenges for gene transfer. Gene 525: 191-199. [Crossref]

155. Meairs S (2015) Facilitation of Drug Transport across the Blood-Brain Barrier with Ultrasound and Microbubbles. Pharmaceutics 7: 275-293. [Crossref]

156. Meng Y, Volpini M, Black S, Lozano AM, Hynynen K, et al. (2017) Focused ultrasound as a novel strategy for Alzheimer disease therapeutics. Ann Neurol 81: 611-617. [Crossref]

157. Horodyckid C, Canney M, Vignot A, Boisgard R, Drier A, et al. (2016) Safe longterm repeated disruption of the blood-brain barrier using an implantable ultrasound device: A multiparametric study in a primate model. J Neurosurg 10: 1-11.

158. O'Reilly MA, Hough O, Hynynen K (2017) Blood-Brain Barrier Closure Time After Controlled Ultrasound-Induced Opening Is Independent of Opening Volume. $J$ Ultrasound Med 36: 475-483. [Crossref]

159. Sennoga CA, Kanbar E, Auboire L, Dujardin PA, Fouan D, et al. (2016) Microbubblemediated ultrasound drug-delivery and therapeutic monitoring. Expert Opin Drug Deliv 11: 1-13.

Copyright: C2018 D'Arrigo JS. This is an open-access article distributed under the terms of the Creative Commons Attribution License, which permits unrestricted use, distribution, and reproduction in any medium, provided the original author and source are credited. 